\title{
DECOLONISING CONTINUING TEACHER PROFESSIONAL DEVELOPMENT IN THE TEACHING OF PHYSICAL SCIENCE THROUGH IMPROVISATION IN RURAL AREAS
}

\section{T. Mabasa*}

Department of Education Studies

e-mail: thomas.mabasa@ul.ac.za / https://orcid.org/0000-0002-8270-4495

\section{S. Singh*}

Department of Mathematics, Science and Technology Education

e-mail: suresh.singh@ul.ac.za / https://orcid.org/0000-0002-8267-6586

*University of Limpopo

Polokwane, South Africa

\section{ABSTRACT}

Calls for the decolonisation of higher education in the world and South Africa in particular, has gained momentum since the student protests in 2015 and 2016. This takes place after some efforts have been made to transform and democratise the higher education landscape. Efforts made include: National Commission on Higher Education, White Paper 3 1997, The Higher Education Act of 1997 and the South African Qualifications Authority (SAQA) Act of 1995 which led to the creation of National Qualification Framework (NQF). The policies had promises on issues of access, equity, equality, inclusivity and social justice. After 20 years of democracy, students started to question the progress or lack thereof in the transformation of higher education in South Africa. They started to make demands for access, free education, decolonisation of the curriculum, changes in the pedagogy and epistemic practices. They also demanded the removal of certain statues on some of the campuses. The protests jolted some academics to start debating and writing about the decolonisation of higher education in South Africa. This was done by picking up different aspects that were made points of focus in terms of decolonisation. Consequently, some academics focused on the decolonisation of the curriculum, some on the higher education system whilst others focussed on teacher education. In this article, we intend to contribute to the debate by focusing on Continuing Teacher Professional Development (CTPD) that is an aspect within teacher education. The focus on CTPD was prompted by the fact that not much has been done on the decolonisation of CTPD in South Africa. Furthermore, this is a critical area, because unless teachers are empowered and reskilled to drive the decolonisation process, they may resist and ultimately render the whole process unworkable. It is based on the study that was conducted, focusing on CTPD in the teaching of physical sciences in some of the rural schools in Limpopo Province. The choice of physical sciences was because physical sciences is a gateway subject and most physics sciences teachers in Limpopo Province are based in rural areas. Generally, 
these schools do not have the appropriate facilities and equipment to teach physical science. Physical sciences teachers also face many challenges such as negative perception about the subject, lack of resources, limited room for professional development, poor teacher training, and inadequate support from within the school and the Provincial Department of Education.

This study focussed on creativity and teacher empowerment by enabling physical sciences teachers to reflect on their implementation of science inquiry. Physical sciences teachers were empowered to be creative in handling scientific inquiry especially in the absence of the necessary scientific equipment. The study was conduct at a Higher Education Institution (HEI) in Limpopo Province where teachers, from rural schools, are specifically invited to the university for the National Science Week, which included a component of ongoing Continuing Teacher Profession Development (CPTD). During the National Science Week physical sciences teachers attend an in-service workshop on Improvisation in Science. Ninety (90) physical sciences teachers participated in this study. Data were generated by using a questionnaire and unstructured interviews. The findings of the study revealed that the success of CTPD is not so much in spending more funds in CTPD programmes, but it is in the approach that is used to prepare teachers to respond appropriately to the needs and the demands of the classroom environment. The article argues that the decolonisation process should prioritise the CTPD programmes at universities. This is due to the fact that teachers as agents of change need to be empowered and reskilled, so that they can be in the forefront of the decolonisation process. This can be achieved by adopting a transformative approach that encourages improvisation in science teaching. This approach to CPTD demands that teachers' professional development should shift from the traditional approach to an approach that empowers teachers to be able to make a meaningful contribution to the classes that they teach.

Keywords: decolonising, continuing teacher professional development, improvisation, physical science teaching, rural areas, empowerment

\section{INTRODUCTION AND BACKGROUND}

The decolonisation of higher education has become an issue that is receiving attention in South Africa. This takes place against the backdrop of transformative efforts that respond to governmental changes in South Africa post 1994. The issue received much attention after the student protests in 2015 where they started to question the existence of symbols like the statue of Cecil John Rhodes at the University of Cape Town. It has brought some kind of awakening and the renewed debate on issues related to decolonisation. This has even led to a situation where even the concept itself has become what Cherrington, Botha and Keet $(2018,1)$ refer to as a concept in "slipperiness" because of multiple meanings that people attach to the concept.

Originally, as Hargreaves (1988) indicates, it meant steps that coloniser countries were forced to take to terminate their political control over what they regarded as political territories and replace it by new relationship as collaborates. In recent years, it has taken a different meaning. Assuming that colonialism ends when political control of the coloniser ends is a big 
mistake. There is also a need to decolonise the mind and what Oelofsen $(2015,130)$ refer to as the "intellectual landscape". This involves the transformation process. Consequently, in the South African context, as Saunders (2017), indicates, the concept is linked to transformation where local knowledge is regarded as important in the development of the country. It is within this understanding, that this study was conducted where the concept is linked to the transformation trajectory of South African Higher Education since 1994.

The transformative trajectory is reflected in different policies that have been formulated since 1994. Lange (2017) divides the process (policy formulation) into two phases, which are access and democratisation (1990s-2001), and throughput and efficiency (2001-2016). Policies include amongst others National Commission on Higher Education, White Paper 3 1997, The Higher Education Act of 1997 and the South African Qualifications Authority (SAQA) Act of 1995 which led to the creation of National Qualification Framework. As Lange (2017) argues, the policy formation trajectory neglected other very important aspects like the curriculum, epistemology and the pedagogy. Consequently, in 2015, the students started to question what they were being taught and the way in which they were taught. They viewed the universities as institutions that are stuck in a colonial agenda of the past.

As a response to the 2015 students protest, articles and papers written by academics focusing on decolonisation emerged. A typology of literature on decolonisation that emerges, can be presented as; literature that focused on curriculum (Hoppers 2017; Jansen 2017; Lange 2017; Le Grange 2016; 2018), teacher education (Mahabeer 2018; Moeketsi 2017; Mudaly 2018; Sayed, Motala and Hoffman 2017; Waghid and Hibbertimagemaqui 2018), Higher Education (Fataar 2018).

It is also important to note that emerging from literature, within teacher education, not much has been written on the decolonisation of Continuing Teacher Professional Development (CTPD). This is despite the importance of CTPD in the upskilling and capacitation of teachers in South Africa. This may be referred to what Waghid and Hibbertimagemaqui (2018) call one of the colonising spaces. There is a need to empower teachers to be able to turn against the colonial practices that are taken as normal in the South Africa context. One way in which teachers can be empowered is through CTPD programmes. It is therefore important that for decolonisation to succeed effectively, institutions of higher education should focus on decolonising their CTPD programmes in order to empower teachers to appreciate the importance of local knowledge in teaching and learning by moving away from the Eurocentric approach. The article therefore, argues that, unless teachers are empowered to repel colonial practices, the project on decolonisation may become a futile exercise. As Waghid and Hibbertimagemaqui (2018) indicate, new approaches to knowledge creation can only emerge 
when teachers resist the current colonial curriculum. It is within this context that this study was conducted focusing on a CTPD programme at a university in Limpopo. The subject selected for the CTPD programme is physical sciences. The selection of physical sciences was guided by the fact that it is one of the subjects where teachers in rural areas face challenges in teaching it. Furthermore, as Moeketsi (2017) posits, there is an urgent need to transform and decolonise teaching and learning of physical sciences due to the dwindling numbers of learner enrolment.

Other general challenges as (Coe, Carl and Frick 2010) and Molapo (2016) indicate, include inadequate teacher training, poor understanding of curriculum reforms, poor involvement of teachers in the curriculum development processes, poor resources, work overload and political interference. As an intervention to the challenges outlined, a CTPD programme becomes one of the most appropriate intervention mechanisms.

It also important to note that there are different forms of CTPD programmes. According to Ono and Ferreira (2010), forms of CTPD can be divided into traditional paradigm and alternative professional development. The traditional form is the CPTD programme that is sometimes called in-service educator staff development. It is usually in the form of workshops, seminars, conferences or courses. Criticisms labelled against this form of CPTD is that it is brief, fragmented, incoherent and decontextualised from the real classroom situation. The criticisms led to another form of CTPD approach known as an alternative professional development. It is based on the constructive theoretical approach. Its emphasis is that knowledge is socially and culturally constructed. Knowledge is a construct which is contextually linked. Teachers as learners are able to construct their own knowledge and consequently, CTPD programmes should be learner-centred. This is the kind of CPTD that takes the context where teachers work into consideration. Learner materials used in the programmes are prepared in such a way that they empower teachers to be able to respond to the challenges in different contexts (Hartshorne 1992). The South African CTPD programme is embedded within the traditional form. This manifests itself in the way in which CTPD programmes are organised. They are usually top-down where teachers are excluded in the designing and developing the programmes and tend to be Eurocentric. Furthermore, literature reveals that CTPD programmes can be done through NGOs, Department of Education and Universities (Hartshorne 1992). This study focused on the CTPD through universities by focusing on the way in which teachers can be empowered to teach physical sciences in schools that are situated in rural areas and are essentially under-resourced. The focus on the CTPD programme through universities was prompted by the gap that exist in literature, as already indicated in the decolonisation of education in South Africa. As Steyn (2008) indicates, this also helped us to look at the extent of decolonisation within CTPD programmes. Consequently, 
the study revolved around the extent to which a CTPD programme at a university in Limpopo contributes towards decolonisation by preparing teachers to improvise in the teaching of physical sciences in rural areas using local knowledge.

\section{PROBLEM STATEMENT}

Poor performances by learners in subjects such as physical sciences continue to be a problem especially in rural schools (Legari 2004; Ramnarain and Fortus 2013; Koti 2016 and Malathi and Rohini 2017). Koti (2016) identifies some of the causes as regular curriculum changes, big classes, learners who are unable to link what is taught with the environment, language that teachers use, teachers who believe that physical sciences is difficult and lack of equipment to conduct experiments. Key to the challenges that they face is the issue of teachers who lack requisite skills to teach learners appropriately. Amongst the different intervention strategies, there is a need for professional development of teachers. The Department of Education intervened by involving universities to train teachers through Advanced Certificate in Education (ACE). Other strategies involved the use of National Science Weeks that are held on different university campuses across the country. These are programmes that are meant to equip practicing teachers with necessary skills to be able to improvise in dealing with different challenges that they encounter in classes. This involves different aspects such as curiosity, creativity and the perseverance of teachers. They go to universities where they interact with other teachers from other schools. Looking at literature, not much research has been done on the experiences of practicing teachers who attend such programmes. As Ramnarain and Fortus (2013) indicate, most research has been done on pre-service period rather than practicing teachers. It is against this background that this study was undertaken focusing on the extent to which the CTPD programme during a Science Week equips teachers to be able to improvise in teaching physical Science in rural areas where there are no resources and equipment. The study addressed the following questions:

\section{Main question}

- $\quad$ To what extent does, a CTPD programme conducted during a Science Week equips teachers to improvise in the teaching of physical sciences?

\section{Sub-questions}

Sub-questions were generated as follows:

- What are the views of teachers in terms of the availability of resources in the teaching of physical sciences? 
- What are the experiences of teachers on improvisation?

- Are there challenges that teachers encounter when they teach physical sciences?

- Does the approach used in a CTPD programme equip teachers to be able to improvise?

\section{THEORETICAL FRAMEWORK}

There are different theories that can be adopted in studying the interaction between lecturers and practicing teachers. Wilsons and Peterson (2006) outline the theories as: learning as a process of active construction and learning as a social phenomenon which emphasises interaction amongst students and traditional conception of learning where learners are viewed as passive participants like sponges to absorb that which the teacher is teaching them. There is a general agreement that learners are not just there to be told what to do, but they are partners involved in the co-construction of knowledge. This means that students come to the class with ideas that are important in the construction of knowledge. Students at the university are trained to teach in this manner. Their training is aligned to the School of Education Conceptual Framework which is under pinned by Critical Social Theory. The theory emphasises social justice and empowerment. Since this study focuses on the extent to which the CTPD programme equips teachers to be able to improvise in teaching physical sciences when there are no resources and equipment, Critical Social Theory was adopted for use as a lens to guide the study. The aspects of Critical Social Theory used in the study relates to empowerment, transformation and reflection. This is in line with the manner in which some authors comment on the theory when they state that "[c]ritical social theory is a mode of reflection that looks critically at processes of social development from the point of view of the obstacles they pose for human flourishing” (Cook 2004, 418).

\section{RESEARCH METHODOLOGY}

In trying to determine the extent to which the CTPD (Science Week programme) equips teachers to be able to improvise in teaching physical sciences, the qualitative research methodology was adopted for use in the study (Miles, Huberman and Saldana 2014; Rahman 2016). The methodology helped us to interact with the participants in the setting and understand the nuances and meanings that they attach to the phenomenon from their perspectives. It also helped us to understand the way in which the participants interpret and make sense of their interaction with learners in the class and their improvisation in the teaching of physical sciences in the class (Mohajan 2018). 


\section{Research design}

There are different research designs that can be adopted for use in qualitative research. Astalin (2013) outlines them as phenomenology, ethnography, grounded theory and case study. For the purpose of this study, which was to determine the extent to which a CTPD programme (Science Week programme) conducted by a University contribute towards equipping teachers to improvise in the teaching of physical sciences, a case study design was adopted for use in the study. As Andrade (2009) indicates, the design helped us to understand the nuances of the context from the perspectives of the participants.

\section{The university's CTPD programme}

The university's CTPD programme was in the form of a science workshop meant to demonstrate that science is practical and relevant in addressing issues in the society where people live. It was also meant to demonstrate that science can be done by using simple everyday available resources. This was meant for teachers in rural areas where there is scarcity of resources to be able to conduct scientific experiments by improvising where there is a need to do so. Teachers were encouraged to adopt a creative, constructive transformative approach when teaching physical sciences. They were challenged to move away from the traditional approach to teaching where their learners followed a recipe style format (worksheet) during practical sessions. Hands-on activities during the workshop showed teachers the benefits of using everyday resources such as balloon, plastic, cups, coated copper, wire, pencil, cardboard, glass, jar, water, empty tins, drinking straws, match stick, cloth, pair of scissors, fishing line, tape, water, candle and coins.

This approach encourages learners and teachers to engage creatively without following formal pre-planned procedures when conducting experiments. This is done to assist leaners to acquire skills, attitudes and values that they will use later in life as scientists. The approach used provide teachers an opportunity to solve problems by engaging in hands-on activities that are fun and simple to do. Similar hands-on activities done with learners will get them to note observations and thereafter seek explanations for their observations. This will allow them to work as a scientist challenges the traditional approach to teaching science.

\section{Sampling}

There are different sampling strategies that can be adopted for use in qualitative research. In this study, a purposive sampling strategy was adopted. As Patton (2015) indicates, the strategy helped us to select cases or participants who had rich information that was pivotal in answering the research question which is to what extent does a CTPD programme contribute towards 
equipping teachers to improvise in the teaching of physical science? Teachers who attended Science Week workshops were purposefully selected to participate in the study. They were all teaching physical sciences in schools that are situated in rural areas.

\section{Data generation}

Data generation was done in 2 phases. In phase 1, teachers were requested to fill in the questionnaire. In phase 2 data was collected using an unstructured interview.

\section{Phase 1}

In phase 1 all teachers who attended Science Week were requested to fill in the questionnaire which focused on the improvisations that teachers use in their science classes and the challenges that they face when teaching science. The number of teachers who completed the questionnaire is 90 . This was done before they started with the workshop in order to get a wider picture in terms of the way in which teachers improvise when teaching physical science. Furthermore, as Brace (2018) indicates, an effort was made to construct a questionnaire that was clear by avoiding ambiguous questions.

\section{Phase 2}

In phase 2, an unstructured interviewing technique was used to generate data. This was done in order to do a follow-up and get clarity on the responses that were not clear from the questionnaire that was administered in phase 1. As Alshenqueeti (2014) indicates, this helped us to allow teachers to give details in terms of the challenges they encountered when improvising in the teaching physical sciences. It also helped us to let teachers elaborate on interesting issues that emerged during interviews as well. For the unstructured interviews, a purposive sample of 15 teachers was used. The purpose of the interviews was to seek clarity from physical sciences teachers about the difficulties they experienced when they had to improvise in their science classes. The focus with the interviews was on the actual individual experiences that were shared by each interviewee. By extracting this information from the teachers, it was possible to recommend strategies that could be used when improvising during science lessons. All the interviews were audio tape recorded and later transcribed so that the data analysis process could be completed. The lengths of the interviews are on average $30-40$ minutes.

\section{Ethical consideration}

The study did take ethical issues into consideration. As Kirk (2007) indicates, it covered 
different ethical issues such as informed consent, confidentiality and power relations. This was done by getting permission from the participants to allow us administer a questionnaire and to interview them before we started with the study. It was made clear to them that they are not obliged to participate in the study and that they had the right to terminate their participation in the study. They were also assured that their identities will be kept anonymous and confidential to avoid any harm that may occur due to their participation in the study. It was also indicated to them that with regard to power relations, as teachers they should not feel that they had to participate to show respect to the lecturers. Furthermore, either they were given a choice to be tape-recorded or not depending on whatever they felt comfortable with.

\section{DATA ANALYSIS AND PRESENTATION OF RESULTS}

The approach adopted in analysing the data from both instruments was to use an integrated approach rather than analysing the data gathered from interviews and questionnaires separately. The analysis of the questionnaire focussed specifically on the challenges that teachers face with respect to practical work and improvisation. The narratives from the interviews helped to provide a backdrop of the schools where the teachers taught. Together, the data analysed provided a holistic view of improvisation in schools, taking into consideration the contexts of the learning environments as well.

This was done in order to organise data into a manageable state. As Alshenqueeti (2014) indicates, there are no fixed approaches of analysing qualitative data. In this study, steps outlined by O'Connor and Gibson (2003) were used to analyse the data. We started by transcribing the recorded interviews. As Baily (2008) indicates, this step helped us to get more familiar with the data and at the same time revisiting the research question of the study. After the data was transcribed, we had to develop codes that were used to identify the data. This was followed by grouping similar kinds of information together into categories. After this step themes were identified emerging from the data. Themes developed include: views of teachers on the availability of resources and infrastructure, experiences of teachers on improvisation, challenges encountered by teachers to improvise and approach used to equip the teachers.

\section{DISCUSSION}

Emanating from the results, there seems to be strong evidence indicating that there is a need to move from the traditional CTPD approach to a decolonised approach. This is where teachers, who are teaching physical sciences, will be equipped to improvise when teaching physical sciences. This becomes clearer when discussing the identified themes. 


\section{Views of teachers on the availability of resources and infrastructure}

In their response to the question on the availability of resources, teachers indicate that there are no resources especially in rural schools. Consequently, they are hampered from achieving their objectives appropriately. They indicated that learning outcome $1 /$ specific aim 2 is difficult to achieve because there are no laboratory facilities. One teacher emphasised this point by stating that "No, it is important for learners to see rather than to hear or read because without laboratory equipment experiments will not be done". This was supported by another teacher who said "It is not possible; theory goes hand in hand with practicals". This finding is in line with the study done by Mkimbili, Tiplic and Odegaard (2017) in Tanzania. They found that teachers' views are that resources were a contextual factor that has an impact on the way in which practicals are done in schools.

In the study, only ten of the ninety teachers questioned had a laboratory in their schools. For this purpose, classrooms converted into science rooms were included as laboratories. This spells out the extent of the problem of lack of relevant infrastructure. The majority of the schools had no laboratories, computer rooms or libraries. Some teachers mentioned that their schools even lack basic amenities such as electricity, running water and telephones. Internet connection is considered a luxury, according to the teachers in the study. Teachers are unable to use simulations or virtual lab experiments due to the unavailability of computers and data projectors.

This lack of basic infrastructure is a very serious problem, especially for teachers who are expected to improvise on so many levels. The concept of improvisation is meant to cater for the times when something lacks. The intention is not to improvise for everything, from lack of infrastructure to large class sizes, to heavy workloads. Clearly, the basic system of education is not functioning as it should and this should be a serious concern for education authorities.

\section{Experiences of teachers on improvisation}

On the question of the teachers' experience on improvisation, responses varied. Some of them indicated that they had limited or no training on improvisation. Others indicated that they had some vague understanding of what it is. One teacher was emphatic by stating that "I do not know what to do since I did not receive any training". This was different from the other teacher although he sounded hesitant by stating that "Yes, I have done a bit of improvising in science while still at university". Some of the teachers even doubted that the workshop would help them. This was revealed by one of the teachers by stating that "No, it is just a camouflaging workshop that leaves us thirsty. More workshops are really needed and can be useful to teachers." Teachers' lack of content knowledge and training on improvisation is highlighted 
below as it impacted on their experiences on improvisation.

\section{Content knowledge}

Teachers in the study were able to critically examine their own content knowledge and they readily acknowledged their limitations. They acknowledged their lack of content knowledge and knowledge about apparatus used in the laboratory. Some of the comments include:

"Teachers do not know the apparatus. They see them as pictures. They do not know how to use or handle them let alone find a substitute."

"I do not know which equipment can be improvised."

"Lack of knowledge, certain things in science seems so challenging, I do not know how to improvise."

These comments by the teachers are indicative of the actual state of education in schools. They also point to other crucial elements that need to be present in any schooling system and are lacking in these schools in the study. These comments were made by teachers who are currently teaching children science. It seems they were not exposed to experiments themselves. Herein, lies the decolonising debate. The South African education system was steeped in a colonial history, followed by apartheid education, both of which were responsible for educating for the purpose of oppressing black people. Things like laboratory apparatus or even science laboratories themselves were seen as tools that could be used by black people to overcome their oppression. Even with democracy, the inequality gap still remains. Although the funding model of schools is designed to favour previously disadvantaged communities, the reality is that the gap widens with schools still under-resourced and basic infrastructure to meet curriculum needs (like laboratories) is still absent. So, the comment that teachers have not even seen or worked with the real apparatus makes sense. It would therefore not be possible for them to improvise for something that they have not worked with in the past.

This once again highlights the need for CTPD programmes to be able to bridge this gap so that this generational problem does not persist. For example, the concept of improvisation must be taught against the background of teachers not having had actual experience of the equipment that they are improvising for. This also has implications for teacher education programmes that these teachers were exposed to. For example, it is possible that some of these teachers have studied through distance education programmes where practical laboratory sessions were not required or done. 


\section{Training}

It is important to note here that teacher learning and training should not end when a qualification is achieved. Learning is a life-long process for both teachers and learners in school. So the role of CTPD cannot be more emphasised here. This implies that CTPD should be an on-going process where training needs are constantly identified and met so that the gap in knowledge is addressed and teachers are constantly up to date with the latest trends in teaching. For example, with the Fourth Industrial Revolution currently taking place, the focus is on electronic forms of learning. It then becomes important for teachers to learn how to incorporate this into the practical lessons. Discussions on innovations in laboratory work can be a good starting ground for CTPD programmes for physical science teachers. In terms of training of teachers, the Department of Education could also introduce a mandatory CTPD points system, similar to that used in Health Sciences and industry.

It is also important to note that the teachers in the study recognised that workshops and in-service short courses can help them to improvise when teaching science.

\footnotetext{
"Some of the concepts are new to us, so workshops help us to understand them."

"More workshops are really needed and can be useful to teachers."

"Since teachers will be workshopped they will acquire more information so that learners will be taught."
}

The purpose of CTPD courses is for teachers to be afforded the opportunity to upgrade and update their knowledge on various matters related to the curriculum that they must deliver. Of course, training is a process that cannot and should not be the responsibility of one structure or organisation. Whilst the Department should formally provide a structure, CTPD activities can also be done at school level by relevant heads of department; curriculum advisors, higher education institutions and other bodies like NGOs.

\section{Challenges experienced by teachers to improvise}

The participants indicated that there are different challenges that they are faced with in schools that affect the way in which they teach physical science. Challenges include large classes which are overcrowded, heavy workload, time constraints, lack of basic amenities such as electricity, running water and finances. One teacher was explicit by stating that "An educator has to see to it that improvisation occurs by buying stuff himself/herself. Sometimes we need to use our own cash. We have to pay to use the internet at a café to find additional information to help us improvise." As Mudulia (2012) indicates, there is a need that there be resources in schools to 
assist teachers in doing their work.

\section{Overcrowding}

Overcrowding is a very real challenge faced by schools. Either through the lack of classroom space or large numbers of learners in some schools, teachers are faced with the challenge of dealing with this problem on a daily basis. Many teachers in the study complained about class size and overcrowding in their schools. These factors make improvising difficult for them. Many of the classes taught by science teachers exceed the acceptable teacher/learner ratio of $1: 35$.

"The classes are overcrowded and this in turn has a negative impact on learners."

"Where there is a big class, it is not easy to accommodate each and every learner - improvisation is very difficult."

The concept of large classes is another issue that requires teachers to be trained in. Not all teachers are able to cope with large classes. However, the concept of improvisation is not made impossible because of large classes or overcrowding. The concept can still be employed with large classes; it requires innovative thinking from the teacher. CTPD courses in this regard can assist the science teacher to come up with ideas that take large groups into consideration. For example, group experiments can be used for large classes.

\section{Time constraints and workload}

Teachers in the study maintain that time constraints and heavy workload makes improvisation extremely difficult. For example, in the case of experiments, they need to do research and conduct the experiments themselves before doing it with learners. Time constraints and heavy workload is due to the number of classes teachers have to teach and the number of learners in each class. Some of the challenges faced include:

\footnotetext{
"Sometimes the learners won't be able to grasp the concepts as I may wish it to be. It is time consuming."

"I do not have enough time to collect materials to use in class or to do the practical first."
}

These issues relate to systemic challenges facing the Department of Education. Increasingly, teachers are required to do more administrative tasks. Large classes mean that more time is needed for marking of activities, tests and examination scripts. In the basic education system, teachers are not afforded the opportunity to have laboratory assistants who would normally 
prepare the experiments for the teachers. These tasks add to the workload of the teacher and the lack of infrastructure, equipment and resources such as chemicals adds to the challenges faced by teachers.

\section{Another important finding}

Teachers were of the view that the learning outcome 1 (old curriculum), specific aim 2 (new curriculum), can only be achieved if proper laboratory facilities are available. Learning outcome 1, specific aim 2 reads as follows: "The learner will be able to act confidently on curiosity about natural phenomena, and to investigate relationships and solve problems in scientific, technological and environmental context", (Department of Education 2002) and "Learners should be able to complete investigations, analyse problems and use practical processes and skills in evaluating solutions" (Department of Basic Education 2011).

The point being made by the teachers was that practical work is not taken seriously although it is catered for in the curriculum policy document. The teachers emphasised what they are able and not able to do.

"There are certain experiments that can be done especially those where equipment is available, for those where equipment is not available, we leave them."

"We do experiments theoretically, not practically."

"We use pictures and the textbook."

It is clearly evident from these comments made by the teachers that they do not consider other options like improvising with respect the conducting experiments. It is here that CTPD can have a role to play. Teachers can be taught and made aware of alternatives from their environment that can be utilised to teach learners. The attitude adopted by the teachers can be changed if they are made aware of how they can improvise in situations where there is no equipment and/or laboratories. What is important to note from these comments is that teachers realise the need for learners to experiment on their own and the need for them to have practical experience in conducting experiments. This is also linked to social constructivist theory where learning takes place in a context with the help of the immediate people surrounding the learner. Learners construct meaning from their experiences and with the help of additional aids like equipment to conduct experiments. When these are not available, improvising allows the same learning to take place by simulating the experience with different learning tools. One of the purposes of introducing the teachers to improvisation during CTPD encounters was to show them how they can use ordinary household items or other relatively cheap teaching aids (like coins and 
balloons) to teach concepts in science.

Teachers find it difficult to improvise in their science classes due to various reasons. The need to improvise places an additional burden on teachers, especially in rural areas, where there is poverty and resources are scarce. Often the burden to improvise is dependent on the teacher, and the learners are not involved in the improvisation process. The CTPD process shifts this burden to enable the teacher to see the need for involving learners in the improvisation process. This is especially true if one considers provision of resources for experiments. If each learner is asked to share in the responsibility of providing household resources, the burden on the teacher is eased.

\section{Approaches used to equip the teachers}

In their effort to equip teachers, the CTPD activity (workshop) of the university adopted an innovative and creative approach to the teaching of physical sciences. They are encouraged to use available basic resources such as balloon, plastic cups, plastic coated copper wire, glass, empty tin cans, drinking straws, pair of scissors, match stick, candles. Some of the teachers indicated that they are benefiting from the approach that encourages innovation and creativity. The teachers indicated that the workshop equips them by link the hands-on activity with the content area. One of the teachers revealed this by stating that "Since I started attending the programme, I see to it that improvisation takes place by buying stuff myself". This was supported by another teacher by stating that "I use worksheets in performing experiments but there is no practicals done". This supports Jacobs' (2013) assertion, in his research, when he indicates that teachers should be able to improvise where resources are not available. Teachers indicated that that they need longer workshops so that they can be more thoroughly equipped. An area of improvisation that can be considered for future workshops is the use of technology eg. Physics Education Technology (PhET) simulations for practical work. The use of PhET simulations can be beneficial for both teachers and learners.

\section{RECOMMENDATIONS}

Based on the findings of this study, we suggest the following recommendations:

- The University should design a short course or a module on "improvising in a science class" to be used for CTPD or be included in an initial science teacher training programme; CTPD must involve teachers in developing programmes that focus on scientific inquiry and investigation; mobile laboratories can be used to temporarily relieve the critical shortage of laboratory space; teachers can also improvise by getting learners actively involved in science related activities by making use of events such as debates, science 
talks and science clubs. This will help learners to actively participate in the process of creativity, innovation and improvisation.

\section{CONCLUSION}

Improvisation remains the important strategy that can be used to deal with shortage of resources in schools that are situated in rural areas. It is also a strategy that can be used to prepare teachers to be able to deal with adverse conditions that are a norm in rural areas. This study has established that through creative and innovative model of CTPD which is transformative; teachers are prepared to be able to teach physical sciences irrespective of the locality of the school. The university which is the setting for this study, is encouraged to design a short course or a module on "improvising in a science class" to be used for CTPD or be included in an initial science teacher training programme. This means that the university should adopt the CTPD approach that demands that teachers' professional development should adopt a transformative approach that prepares teachers to make a meaningful contribution in the teaching of physical sciences. This approach of using simple everyday stuff to teach physical sciences is a step in the right direction to decolonise of CTPD which currently focuses on the use of sophisticated equipment in the training of teachers.

\section{REFERENCES}

Alshenqueeti, H. 2014. Interviewing as a data collection method. English Linguistics Research 3(1): 39-45. www.sciedu.ca/e/r (Accessed 6 March 2019).

Andrade, A. D. 2009. Interpretive research aiming at theory building: Adopting and adapting the case study design. The Qualitative Report 14(1): 42-60. https://nsuworks.nova.edu/cgi (Accessed 4 March 2019).

Astalin, P. K. 2013. Qualitative research designs: A conceptual framework. International Journal of Social Science \& Interdisciplinary Research 2(1): 118-124. https://pdfs.semanticscholar. org/baa7 (Accessed 4 March 2019).

Baily, J. 2008. First steps in qualitative data analysis: Transcribing. Qualitative Data, Family Practice, Oxford Academic 25(2): 127-131. https://academic.oup.com/fampra/article (Accessed 6 March 2019).

Brace, I. 2018. Questionnaire design: How to plan, structure and write survey material for effective market research. $4^{\text {th }}$ Edition. London: Kogan Page.

Cherrington, A. M., M. Botha and A. Keet. 2018. "Decolonising" education transformation. South African Journal of Education 38(4): 1-4.

Coe, K., A. Carl, and L. Frick. 2010. Lesson study in continuing professional teacher development: A South African case study. Acta Academica 42 (4): 206-230.

Cook, D. 2004. Adorno, Habermas and the search for a rational society. London, Routledge.

Department of Education. 2002. Revised National Curriculum Statements: Grade R-9 (Schools): Natural sciences. Pretoria: Government Printer.

Department of Basic Education. 2011. Curriculum and Assessment Policy Statement: Grades 10-12 Natural Sciences Grade 7-9. Pretoria: Government Printer. 
Fataar, A. 2018. Decolonising education in South Africa: Perspectives and debates. Educational Research for Social Change 7: vi-ix. www.scielo.org.za (Accessed 27 April 2019).

Hargreaves, J. D. 1988. Decolonization in Africa. London: Longman.

Hartshorne, K. 1992. Crisis and challenge: Black education 1910-1990. Cape Town: Oxford University Press.

Hoppers, C. A. O. 2017. Of sediments and trails in decolonizing the curriculum: A transformative response from an African perspective. National Education Collaboration Trust Education Dialoguesa.

Jacob, A. K. 2013. Instructional materials and improvisation in physics class: Implications for teaching and learning. Journal of Research \& Method in Education 2(5): 38-42.

Jansen, J. 2017. Decolonising the university curriculum given a dysfunctional school system? Journal of Education 68: 3-14. www.scielo.org.za (Accessed 27 April 2019).

Kirk, S. 2007. Methodological and ethical issues in conducting qualitative research with children and young people: A literature review. International Journal of Nursing Studies 44: 1250-1260. https://pdfs.semanticscholar.org (Accessed 6 March 2019).

Koti, M. 2016. Challenges experienced by physical science teachers with the implementation of the curriculum and assessment policy statement in selected Eastern Cape Schools. Unpublished MEd Dissertation. Pretoria: UNISA.

Lange, L. 2017. 20 Years of higher education curriculum policy in South Africa. Journal of Education 68: 31-58. www.scielo.org.za/pdf/jed/n68/04.pdf (Accessed 4 May 2019).

Legari, K. 2004. Teaching physical science in rural (Under-resourced) Secondary Schools. Unpublished MEd Dissertation. Durban: University of Durban-Westville.

Le Grange, L. 2016. Decolonising the university curriculum. South African Journal of Higher education 30(2): 1-12. http://dx.doi.org/10.20853/30-2-709 (Accessed 27 April 2019).

Le Grange, L. 2018. Decolonising, Africanising indigenising and internationalising curriculum studies: Opportunities to (re)imagine the field. Journal of Education 74: 4-18. doi: http//dx.doi.org/ 10.17159/2520-9868/i74a0/

Mahabeer, P. 2018. Curriculum decision-makers on decolonising the teacher education curriculum. South African Journal of Education 38(4): 1-13.

Malathi, S. and R. Rohini. 2017. Problems faced by the physical science teachers in doing practical work in higher Secondary Schools at Aranthangi Educational district. International Journal of Science and Research 6(1): 133-135.

Miles, M. B., H. P. Huberman and J. Saldana. 2014. The qualitative data analysis: A method source book. $3^{\text {rd }}$ Edition. London: Sage.

Mkimbili, S. T., D. Tiplic and M. Odegaard. 2017. The role played by contextual challenges in practising inquiry-based science teaching in Tanzania Secondary Schools. African Journal of Research in Mathematics, Science and Technology Education 21(2).

Mohajan, H. K. 2018. Qualitative research methodology in social sciences and related subjects. https://mpra.ub.uni-muechen.de/85654

Molapo, M. R. 2016. How educators implement curriculum changes. Unpublished MEd Dissertation. Pretoria: University of Pretoria.

Moeketsi, F. T. 2017. Creating sustainable physical sciences learning environments: A case for decolonised and transformative learning-research. Perspective in Education 35(2): 85-98. https://journals.co.za/content/journal (Accessed 11 May 2019).

Mudaly, R. 2018. Towards decolonising a module in the preservice-science teacher education curriculum: The role of indigenous knowledge systems in creating spaces for transforming the curriculum. Journal of Education 74: 47-66. doi: http://dx.doi.org/10.17159/2520-9868/i74a04 (Accessed 27 April 2019).

Mudulia, A. M. 2012. The relationship between availability of teaching/learning resources and 
performance in Secondary School science subjects in Eldoret Municipality, Kenya. Journal of Emerging Trends in educational Research and Policy Studies 3(4): 530-536.

O'Connor, H. and N. Gibson. 2003. A step-by-step guide to qualitative data analysis. Pimatiziwin: A Journal of Aboriginal Indigenous Community Health 1(1): 63-90.

Oelofsen, R. 2015. Decolonisation of the African mind and intellectual landscape. Phronimon 16(2): 130-146. www.scielo.org.za (Accessed 27 April 2019).

Ono, Y. and J. Ferreira. 2010. A case study of continuing teacher professional development through lesson study in South Africa. South African Journal of Education 30: 59-74.

Patton, M. Q. 2015. Qualitative research and evaluation methods. $3^{\text {rd }}$ Edition. Thousand Oaks CA: Sage.

Ramnarain, U. and D. Fortus. 2013. South African physical sciences teachers' perceptions of new content in a revised curriculum. South African Journal of Education 33: 1-15.

Rahman, S. 2016. The advantages and disadvantages of using qualitative and quantitative approaches and methods in language "Testing and assessment" research: A literature review. Journal of Education and Learning 6(1): 102-112. http://www.researchgate.net (Accessed 3 March 2019).

Saunders, C. 2017. Decolonization in Southern Africa: Reflections on the Namibian and South African cases. Journal for Contemporary History 42(1): 99-114. https://dx.doi.org/10.18820/ 24150509/JCH42v1.6 (Accessed 27 April 2019).

Sayed, Y., S. Motala and N. Hoffman. 2017. Decolonising initial teacher education in South African universities: More than an event. Journal of Education 68: 59-92. www.scielo.org.za (Accessed 27 April 2019).

Steyn, G. M. 2008. Continuing professional development for teachers. Koers 73(1): 15-31.

Waghid, Z. and L. Hibbertimagemaqui. 2018. Decolonising preservice teachers' colonialist thoughts in higher education through defamiliarisation as a pedagogy. Educational Research for Social Change 7. www.scielo.org.za (Accessed 11 May 2019).

Wilson, S. M. and P. Peterson. 2006. Theories of learning and teaching what do they mean for educators? Washington: National Education Association. 